\title{
Building a Vibrant Future for School Librarians through Online Conversations for Professional Development
}

\author{
Judy O'Connell \\ Courses Director \\ School of Information Studies \\ Charles Sturt University \\ PO Box 588, Wagga Wagga NSW \\ Australia \\ juoconnell@csu.edu.au
}

\begin{abstract}
Technology and social media platforms are driving an unprecedented reorganization of the learning environment in and beyond schools around the world. Technology provides us leadership challenges, and at the same time offers opportunities for communication and learning through technology channels to support professional development. School librarians and teacher librarians are often working as the sole information practitioner in their school, and need to stay in touch with others beyond their own school to develop their personal professional capacity to lead within their school. The Australian Teacher Librarian Network aims to make a difference, and supports school library staff in Australia and around the world to build professional networks and personal learning connections, offering an open and free exchange of ideas, strategies and resources to build collegiality. This ongoing professional conversation through online and social media channels is an important way to connect, communicate and collaborate in building a vibrant future for school librarians.
\end{abstract}

Keywords: technology, social media, communication, leadership, collaboration

It is important to support school librarians, teacher librarians, and school library staff in an ongoing professional conversation through a multiplicity of channels to support them in managing libraries, promoting reading and information literacy, and adapting to the digitally enhanced needs of their students where there is a perfusion of technology in the local or community environments. To support and nurture learning in these evolving environments is a leadership challenge that is both exciting and challenging encompassing many aspects of literacy, technology and professional development in collaboration with students and teachers (Fontichiaro 2010; Howard 2010; Killeen 2009; O'Connell, J. 2012). This is why using digital mediums to connect, communicate and collaborate is an important means to build collegiality beyond academic and professional development programs, to enhance professional networks and personal learning connections.

What is the conversation?

The international longitudinal research study of emerging technologies in K-12 education The Horizon Report K-12 (Johnson et al, 2013) has been charting ongoing technology changes and highlighting the impacts and evolving needs in the teaching, learning, and creative inquiry practices in education. According to the near term horizon of the latest Horizon Report, that is within the current year, there are two related by distinct categories of influence: cloud computing and mobile learning. These are becoming more and more pervasive in everyday life in much of the world, and as a result the increasing expectations 
of students to work, play and learn via cloud-based services and apps on their mobile devices is gaining prominence. Cloud computing has already transformed the way we are using the Internet to help us manage information, communication, data storage and access, as well as collaborative work. Mobile learning provides gateways to endless learning, collaboration, and productivity fostered by the Internet.

Project Tomorrow (2013) reveals that school students are using social media to connect, collaborate and create content in ways that are especially meaningful for them, and that are new to past generations. Students are adapting these tools and resources to enhance and extend the learning process, and to achieve learning goals. Where internet access is steady and reliable, students are already busy personalizing their education experiences through ubiquitous online interactions. Social media and digital tools and resources have transcended the classroom and are emerging strongly as key components of 21 st century school to home communications.

The evidence is that technologies and social media platforms are driving an unprecedented reorganization of the learning environment in and beyond schools. These disruptive shifts are already reshaping the workforce landscape and the skills required (Davies et al, 2011), establishing lifelong and life-wide learning as the central paradigm for the future (Redecker et al, p.10). Schools have a responsibility to prepare students to move from the world of school to the world of adulthood, employment, further education, vocational training, and community participation. Schools can meet future learning needs by creating a sustainable learning ecology that is shaped by the ubiquity of information, globally responsive pedagogical practices, and driven by collaboration and informal learning in multiple access points and through multiple mediums.

It is this digital environment that seems to have become a key driving force affecting the context of curriculum engagement and driving changes in the information ecology within which school library services are positioned. Staff in school libraries need ways to keep 'upto-date' and then ways to extend personal professional capacities. Luckily the information sector already has wonderful librarians providing professional opportunities to anyone who cares to 'join': many avenues are available.

In 2006 Helene Blowers and the team at the Public Library of Charlotte and Mecklenberg County launched the first 23 things program that took the library world by storm. This selfpaced course offered library workers the chance to build their professional knowledge and skills at their own pace using a fun professional development online tool. This program has been replicated around the world as a vibrant way to engage in exploration and learning in non-formal settings. In Australia The State Library of Victoria provides the Personal Learning Network (PLN) program <http://www.slv.vic.gov.au/pln>, which is a self-paced online program for school library staff, educators, learning support personnel and curriculum leaders. The program is designed for those new to the world of web-based learning, as well as people keen to enhance their existing online skills and experience. The PLN program is presented in association with the School Library Association of Victoria, and was developed with support from the Department of Education and Early Childhood Development. In 2013 The State Library of NSW launched the English version of 23 Mobile Things , $<$ http://23mobilethings.net> which was developed for the library team at Guldborgsundbibliotekerene in Danish <http://23mobileting.org/>. This program explores apps and social networking tools for both Android and iOS mobile platforms, and is another example of online professional opportunities for school librarians.

These initiatives are all online, and through online engagement remove the fear of distance, and the worry of learning new things. These environments nurture professional conversations, and help librarians the world over to maintain vibrant library services. 
In Australia we face many challenges in our school libraries, and amongst these the latest one has been to respond to new media environments. The expanding scope of our services in school libraries is a vitally important aspect of the professional development opportunities for information professionals we know as teacher librarians. The School of Information Studies (www.csu.edu.au/faculty/educat/sis/) at Charles Sturt University (CSU) is a national and international provider in the design and delivery of a comprehensive suite of courses in library and information studies, providing two programs relevant to staff in school libraries. The Master of Education (Teacher Librarianship) has been available for Australian and international study for many years, and the new Master of Education (Knowledge Networks and Digital Innovation) targets the additional needs for specialist digital environments.

Alongside this commitment to school libraries, the teacher librarianship team at CSU has been working voluntarily over the last 10 years to facilitate and empower online conversations by supporting the OZTL_NET listserv as a professional service to the school library sector.

OZTL_NET was originally created as a discussion list for information professionals working in Australian schools, by the teacher librarianship academic staff at CSU. Since then it has grown to a community of more than 3,000 teacher librarians, information professionals, and those working or interested in school libraries. This email-based service, run as a listserv using Mailman (www.gnu.org/software/mailman/index.html), though quite old in the style of service it represents, is still very much a current and useful tool for many staff (especially where email access is the best form of digital conversation), and sometimes a lifesaver in getting quick assistance with a problem.

However, the growing importance of utilising web-based and mobile-device-enabled tools for communication meant that it was time to rework and expand the potential of OZTL_NET by developing the potential of this very stable discussion list in a number of social media ways. By casting a wide net into new areas of collaboration OZTL_NET wanted to ensure that a cross-section of information professionals in schools could be supported in their own learning journey, and through their own online conversations for professional development. Social media is a perfect way to allow synergy in discussion and sharing of resources. Social media also provides a strong platform for showcasing the conversation, activities, and achievements in the day-to-day activities of a school library.

By developing a new OZTL_NET portal at < http://oztlnet.com> CSU sought to establish a platform that could change, evolve and adapt to needs and social media developments. So, Australian teacher librarians (and many others who join the groups from around the world) have new choices to suit their personal needs in addition to the regular email discussion list.

Here is what is currently on offer:

- Share a link on the email discussion list (listserv) and take the option to store it for easy retrieval any time in the Diigo group! $<$ https://groups.diigo.com/group/oztl_net> Anyone is free to join, but a contributor is approved at their first share.

- Share library images in Flickr group <http://www.flickr.com/groups/oztl_net/> because we need to collect the ideas from around Australia.

- 'Like' us on Facebook page and include us in your News Feed $<$ https://www.facebook.com/OztINet>. Share things you find, and get into the conversation. 
- Join online conversations at the Australian Teacher Librarian Network Google Community. <http://bit.ly/OZTLNETGooglePlus> You'll even be able able to 'hangout' with your TL friends!

- Perhaps 140 characters on Twitter will be just the thing for you <https://twitter.com/OZTLNet>. Follow @OZTL_NET on Twitter and use the hashtag \#oztlnet as just another way to stay in touch and build the TL community.

To make all this possible, and still provide access to the vital information for the OZTL_NET listserv, visit the fantastic new web portal at <http://oztlnet.com>, where all the links to the social media sites, as well as access to the email discussion list, are provided.

\section{Building online conversations with social media}

The community that has grown through OZTL_NET has also supported teacher librarians and school library staff in a number of other exciting ways, as they expand their reasons to collaborate through online conversations.

The Digital Citizenship in Schools Facebook page <https://www.facebook.com/DigitalCitizenshiplnSchools> originally established by Judy O'Connell, is now updated and managed by a group of Australian teacher librarians who are committed to this endeavour purely through professional interest and a desire to maintain a vibrant online information resource and facilitate conversations around this vital topic, and have no formal institutional affiliations. What brought them together WAS the collaborative environment of Facebook. This is a unique example of collaborative practice for the benefit of the profession! Members of the Facebook group are drawn from around the world with members from 20 different countries.

This facebook site is connected to the Digital Citizenship Diigo group <https://groups.diigo.com/group/digital-citizenship-in-schools> which provides a wonderful way to curate links related to this topic. With 230 members this group has a huge potential to grow, thereby contributing to the global conversations related to digital citizenship, and to support school libraries at whatever stage of development they may be at.

What these examples are showing us is the capacity to build online conversations for professional development in new social media spaces. There is a great deal of rich content online, and by working together teacher librarians, school librarians, and school library staff can achieve change at a global level.

The new core information research tools for supporting developing needs in networked online environments include:

- Micro blogging tools for information sharing by teachers, students, classes and the school community in primary and secondary schools. E.g. Edmodo, Google+ or Twitter

- Social Bookmarking and tagged collections eg. Diigo, Delicious, PearlTrees and Flickr.

- Collaborative writing, editing, mind mapping and presentation tools e.g. Google docs, Exploratree, Voicethread, Mindmeister and Wikispaces.

- Tools for online information management, writing and collaboration e.g. Goodreads, Zotero, Easybib

- Information capture and sharing in multiple platforms and devices e.g. Dropbox, Evernote.

The goal is for teacher librarians, school librarians and school library staff to be socially connected through online communities and ways of publishing to know 'what's new' and 
'what's important' as flexible information sources become more and more part of curriculum services in schools.

Professional development is not a solitary activity, and also not always a face-to-face activity. The $21^{\text {st }}$ century world demands information literacy practices that include personalized and collaborative information aggregation and knowledge sharing. It is all about knowing, learning, sharing, and teaching all in one!

There are many opportunities for building vibrant futures through online conversations and social media environments. More information and content that can be the topic of your next professional development session is available for anyone to use at the following link http://bit.ly/LibrariesSocialMedia.

This site supports professional development activities related to Revolutionising Libraries with Social media, and is another example of a resource made and shared online with anyone around the world!

Technology and social media platforms are here to stay. Members of the Australian Teacher Librarian Network are already active and energised to build a vibrant future for their school libraries though, amongst other things, maintaining and promoting online conversations for professional development.

Join OZTL_NE or join a group online today, in your region, your country, or the world. You will not look back.

\section{References}

Davies, A., Fidler, D., \& Gorbis, M. (2011). Future work skills 2020. Institute for the Future for the University of Phoenix Research Institute: California.

Fontichiaro, K. (2010). Pride and prejudice and technology leadership. In S Coatney (ed.), The many faces of school library leadership, Libraries Unlimited, California, pp. 101113.

Howard, J. (2010). The teacher-librarian as a curriculum leader. In S Coatney (ed.), The many faces of school library leadership, Libraries Unlimited, California, pp. 85-97.

Johnson, L., Adams Becker, S., and Cummins, M. Estrada, V., Freeman, A., and Ludgate H. (2013). NMC Horizon Report: 2012 K-12 Edition. Austin, Texas: The New Media Consortium.

Killeen, E. (2009). Yesterday, today, and tomorrow: transitions of the work but not the mission. Teacher Librarian, 36(5) pp. 8-13.

O'Connell, J. (2012). Change has arrived at an iSchool library near you. In P Godwin \& J Parker (eds), Information literacy beyond Library 2.0., Facet Publishing, London. pp. $215-228$.

Project Tomorrow. (2013). From chalkboards to tablets: The digital conversion of the K-12 classroom. Speak-Up National Research Project. http://www.tomorrow.org/speakup/pdfs/SU12EducatorsandParents.pdf 
Redecker C., Leis M., Leendertse M., Punie Y., Gijsbers G., Kirschner P., Stoyanov, S. \& Hoogerveld, B. (2011). The future of learning: preparing for change, Institute for Prospective Technological Studies, JRC European Commission.

\author{
Biographical note \\ Judy O'Connell is Courses Director in the School of Information Studies, Faculty of \\ Education at Charles Sturt University, Australia. From 2008-2010 she was Head of Library \\ and Information Services at St Joseph's College, Hunters Hill, Sydney. In 2006-2007 she \\ was an Education Consultant in Library and Web 2.0 developments for 80 primary and \\ secondary schools in the Western Region of Sydney. Her professional leadership \\ experience spans K-12 and tertiary education, with a focus on libraries, library design, \\ gaming, virtual worlds, curriculum and professional development in school libraries and \\ classrooms in a digitally-enriched environment. Judy writes online at http://judyoconnell.com
}

